\title{
GEM-QUALITY CHRYSOPRASE FROM HANETI-ITISO AREA, CENTRAL TANZANIA
}

\author{
KARI A. KINNUNEN and ELIAS J. MALISA
}

\begin{abstract}
KINNUNEN, KARI A. and MALISA ELIAS J., 1990: Gem-quality chrysoprase from Haneti-Itiso area, Central Tanzania. Bull. Geol. Soc. Finland 62, Part 2, $157-166$.

Gem-quality, apple-green, Ni-bearing chalcedonic quartz occurs as near-surface veins in silicified serpentinite in the Haneti-Itiso area, Central Tanzania. AAS determinations revealed a high $\mathrm{Ni}$ content, $0.55 \mathrm{wt} . \%$, and low $\mathrm{Co}$ and $\mathrm{Cr}$ contents of 120 and 1 ppm respectively. NAA determination revealed near chondritic REE contents. X-ray diffraction determinations showed that the chrysoprase consists mainly of alpha quartz with some opal-CT. The gemmological properties are: refractive indices from 1.548 to $1.553( \pm 0.002)$, mean specific gravity 2.56 , hardness about 7 on Moh's scale, inert to ultraviolet radiation, green through Chelsea filter, and absorption in the deep red and violet part of the optical absorption spectrum. The results confirm the identity of the material as chrysoprase.

Microscopically the Tanzanian chrysoprase consists of spherules which are highly disordered, concentric, and composed of bipyramidal quartz, chalcedony, quartzine, and opal-A. They were classified into four main types according to the shell arrangement. The diameter of the spherules ranged from $40 \mu \mathrm{m}$ to $77 \mu \mathrm{m}$. Fluid inclusion types in the bipyramidal quartz were monophasic, low-temperature type. The spherules, silica types and REE contents suggest that this chrysoprase was deposited by evaporation of surface waters connected with the silicification of the serpentinites. Genetically analogous formations, common in Africa, include M-fabric type, weathering profile silcretes.
\end{abstract}

Key words: gems, chrysoprase, chemical composition, X-ray diffraction data, spherules, fluid inclusions, crystallization, Archaean, Tanzania.

Kari A. Kinnunen: Geological Survey of Finland, SF-02150 Espoo, Finland.

Elias J. Malisa: University of Dar es Salaam, P.O. Box 35052, Dar es Salaam, Tanzania.

\section{Introduction}

In 1982 one of us (K.A.K.) observed an unusual surface texture (Fig. $3 \mathrm{~A}$ ) on some of the first cabochons cut in Finland from recently discovered chrysoprase (variety name for gemquality, apple-green, Ni-bearing chalcedony) occurring in the Haneti-Itiso area, Central Tanzania (Fig. 1). The textures consisted of disordered spherules of silica much like that in some opals (see Darragh et al. 1976) only larger in size.
The microtextures of gemstones and their genetical implications have received little attention. However, microtextures can be used in the gem testing of fine-grained materials (e.g., Kinnunen 1982 ) in much the same way as mineral and fluid inclusions in crystals (Gübelin and Koivula 1984). The finding of large silica spherules in Tanzanian chrysoprase provided impetus for a detailed study.

Chirysoprases have been studied extensively, mainly because of the well-known connection of 


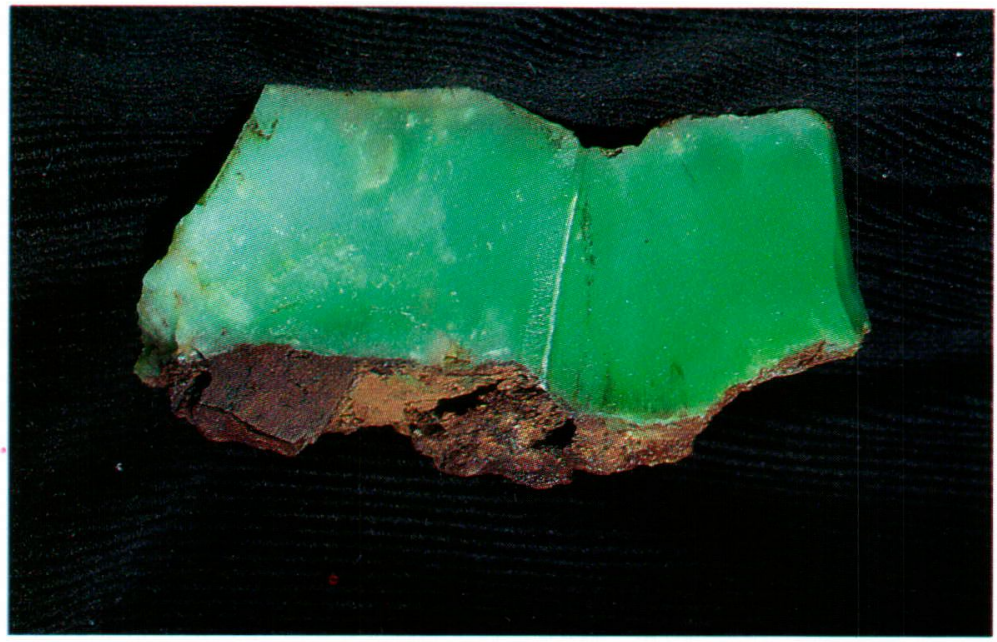

Fig. 1. Vein of gem-quality chrysoprase from the Haneti-Itiso area, Tanzania. The brown host rock seen on the sample is silicified serpentinite, siliciophite. Length of specimen is $9 \mathrm{~cm}$. Photo by K. A. Kinnunen.

these gem minerals with some nickel occurrences in serpentinites (Table 1). This connection has been used in prospecting for chrysoprase. Komov et al. (1987) have, based on the deposits in Kazakhstan, specified favourable indications for gem chrysoprase as being serpentinized (mainly lizarditic) ultrabasic rocks containing from 2 to 3.3 per cent nickel, which additionally show silicified weathering crusts with quartz, chalcedony and prasopal veins along faults.

The samples of Tanzanian chrysoprase were collected together with field observations by one of the authors (E.J.M.) in 1980 and 1984. This was done in connection with the study of gem materials and their potential exploitation in Tanzania (see Malisa 1987, Malisa and Muhongo 1990). The first mention in the literature of gemquality silica types (green opal, prasopal, and chrysoprase) occurring at Haneti Hill was by Gübelin (1975) and Schmetzer et al. (1976).

The quarrying of chrysoprase at Haneti-Itiso area was commenced by a private Greek prospector George Pappas. Today, the State Mining Corporation of Tanzania (STAMICO) holds claim

Table 1 . The main occurrences recorded as producers of gem-quality chrysoprase.

\begin{tabular}{lll}
\hline Locality & Host rocks & Reference \\
\hline 1. Lower Silesia, Poland & magnesite veins in serpentinite & 1 \\
2. Sarakulbaldy, Central Kazakhstan, USSR & Ni-deposit in serpentinite & 2 \\
3. Revdinsk, Ekaterinburg, Urals, USSR & Ni-ochre mine & 3 \\
4. Visalia, Tulare, California, USA & serpentinite & 4 \\
5. Nickel mountain, Oregon, USA & Ni-ores in serpentinite & 5 \\
6. Minas Gerais and Goias, Brazil & nickel ores \\
7. Queensland, Australia & ultrabasic rocks, & 4 \\
8. Haneti-Itiso area, Tanzania & nickeliferous laterite \\
\hline
\end{tabular}

Data from: (1) Kozlowski and Sachanbinski (1984)

(2) Osipov and Klimovistkaya (1977)

(3) Bauer (1904)

(4) Webster (1983)

(5) Kunz (1892)

(6) Connolly (1980)

(7) this study 
to the chrysoprase quarries and extraction of the chrysoprase is done through its subsidiary company, the Tanzanian Gemstone Industry Ltd.

\section{Geological setting}

The Haneti-Itiso area is located in QDS 124, Kelema and 143, Meia Meia (Pallister 1960, 1963). The rocks are Archaean, and belong to the Dodoman formation, which consist of metamorphosed ultrabasics forming a line of hills running in a north-westerly direction. The dominant rock type in the Haneti-Itiso intrusive complex is a silicified and ferruginized serpentinite, within which are pods and zones of anthophyllite asbestos, chlorite-magnesite-serpentinites, silicified and ferruginized to varying degrees. The ultrabasic rocks of the Haneti-Itiso complex are cut by numerous veins of magnesite and less commonly, asbestos (gedrite). The silicified and ferruginized serpentinite sporadically contains nickel-bearing magnesite as abundant finely disseminated grains.

Due to tropical weathering the rocks have been silicified when silica, removed in aqueous solution from decomposed rocks, was subsequently reprecipitated as veins of chalcedony or chalcedonic quartz (chrysoprase). Gem-quality chrysoprase occurs as thin discontinuous veinlets within the ultrabasic rocks. Bright specks of magnesite are disseminated through a dull-brown 'flinty' groundmass of dunite and peridotite in outcrops on the Mnakuru hill, whilst on another hill further to the north-west, epidote-clinozoisite-tremolite schist, derived from rocks of gabbroic composition is dominant. The emplacement of the ultrabasic rocks is thought to have been controlled to some extent by major NW and minor NE-trending fractures and shear zones.

\section{Description of material}

Chrysoprase specimens were collected from the Kwahemu, Senato and Msani hills about $10 \mathrm{~km}$ southeast of Kwahemu ujamaa village. Nickelrich magnesite veins have been prospected in the area, but the only mining activity done up to now at the Haneti-Itiso area is quarrying of gemquality and ornamental chrysoprase. Chrysoprase occurs near the surface as irregular veins (Fig. 1), commonly $1-5 \mathrm{~cm}$ in width in siliciophites - serpentinites silicified to red or redbrown flinty rocks. Green opal occurs sporadically in the same area. Four chrysoprase vein samples in total were selected for the study of microtextures and one for chemical analysis and $\mathrm{X}$-ray diffraction determination.

\section{Chemical analysis}

Atomic absorption spectrophotometric (AAS) determinations showed high Ni contents: 0.55 wt.\%. Other trace elements analyzed by AAS were (in ppm): Co 120, Zn 84, Fe 40, Mn 8, Cu 4 and $\mathrm{Cr} 1$. Neutron activation analysis (NAA) showed the following lanthanoid spectrum (in ppm): La below 1, Ce 1.51, Nd 1.07, Sm 0.19, Eu 0.090, Tb 0.023, Tm 0.11, Yb 0.60, and Lu 0.12 . These rare earth element (REE) contents are rather close to chondritic values (Fig. 2). The values are higher than in typical serpentinites although they show similar LREE/HREE ratios to those of serpentinites (see Frey 1984). The chondritic REE contents in chrysoprase suggest en-

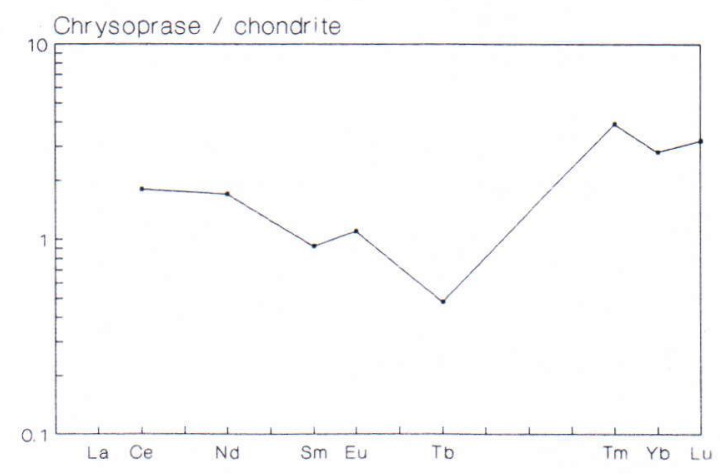

Fig. 2. Rare earth element (REE) pattern, chondrite normalized, from gem chrysoprase, Haneti-Itiso area, Tanzania. 
richment from serpentinites during weathering processes (e.g., Fleet 1984). Beside these trace elements, the NAA determination showed the Au contents of $0.019 \mathrm{ppm}$, Th below $0.4 \mathrm{ppm}$ and $\mathrm{U} 0.3 \mathrm{ppm}$.

\section{X-ray diffraction data}

The X-ray diffractograms confirmed the presence of alpha quartz. Diffuse lines of opal-CT were detected from unheated material in a few $\mathrm{X}$-ray diffraction films (Debye-Scherrer powder camera). Heated material showed only quartz lines. These data, together with the chemical analyses are typical for chalcedonic silica. The high $\mathrm{Ni}$, and low $\mathrm{Co}$ and $\mathrm{Cr}$ contents confirm the initial identification of this green chalcedony type from Tanzania as chrysoprase (according to the definition in Frondel 1962 and Webster 1983).

\section{Cause of the green colour}

The green colour of the Tanzanian chrysoprase is ascribed to the high, $0.55 \mathrm{wt} . \% \mathrm{Ni}$ contents. Frondel (1962) has attributed the green colour of chrysoprases to a nickel hydrate silicate. However, no lines of any crystalline nickel-bearing mineral phase could be detected from the X-ray diffraction films (Debye-Scherrer powder camera) obtained from the deep green parts of Tanzanian chrysoprase, even after exposure times of several hours. Schmetzer et al. (1976) have studied the infrared spectrum of chrysoprase from Haneti hill, Tanzania. Their results suggest that the green colour is caused by $\mathrm{Ni}^{2+}$ ions occurring in $\mathrm{Mg}^{2+}$ sites in clay minerals.

\section{Gemmological properties}

The practical identification of gem minerals differs from ordinary mineralogical procedures. Non-destructive simple methods, called gemmo- logical tests, are preferred, mainly because such methods are also suitable for expensive cut stones (Chuboda and Gübelin 1966, Lewis 1977, Liddicoat 1977, Anderson 1980, Webster 1983, Gübelin and Koivula 1986, Matlins and Bonanno 1989). Although these tests are usually not able to scientifically prove the identity of a mineral, they are usually accurate enough for practical purposes. Today the science gemmology is largely a search for such simple methods following determination by more sophisticated instrumental studies. The goals are simple tests, which jewellers equipped with modest instruments (traditionally refractometer, spectroscope and stereomicroscope) are able to perform in their shops. Therefore, every description of a new gemstone locality should include as much as possible of this kind of information.

\section{Refractive indices}

The refractive indices were measured with a Rayner jeweler's refractometer using sodium light. The accuracy of the refractometer used was established with an oriented quartz crystal as \pm 0.002 . The indices of chrysoprase were measured from small polished slabs. One, or in some cases two diffuse shadow edges were observed. The readings ranged from 1.548 to 1.553 $( \pm 0.002)$. The distant vision technique applicable for cabochons was tried, but gave inaccurate results.

The jeweler's refractometer measures the refractive index from polished surfaces by the principle of total reflection and the critical angle. The minimum area required for accurate measurements is about $1 \mathrm{~mm}^{2}$ (Hurlbut 1984). The measurement gives a total of several indices present in very fine-grained aggregates. Anderson (1980) and Webster (1983) have interpreted the two refractive indices generally obtained from chalcedony as 'form birefringence'. They suggest that it is caused by two materials having slightly different refractive indices. However, in the case of Tanzanian chrysoprase the values correspond to alpha quartz. The low birefringence compared 
to quartz can be explained by the orientation of quartz fibers in the spherules composing the chrysoprase.

\section{Colour}

The colour was determined with Munsell colour cards in reflected incandescent light. The most intense colour observed was brilliant green, $5 \mathrm{G} \mathrm{6/6}$. The more faintly coloured varieties ranged from pale green, $5 \mathrm{G} 7 / 2$, to very pale green, $10 \mathrm{G} 8 / 2$.

\section{Specific gravity}

The specific gravity was measured with a Kraus-Jolly specific gravity balance. The measurements ranged from 2.53 to 2.64 with the average of ten measurements being 2.56. Most of the scatter is ascribed to the varying porosity and opal content of the chrysoprase material. The mean value obtained is typical of chalcedony in general.

\section{Diaphaneity}

Translucence together with colour and size, is the main property used in assaying the quality of rough gem chrysoprase (Komov et al. 1987). The Tanzanian chrysoprase is translucent at thicknesses of $1-2 \mathrm{~cm}$ with some turbid areas seen in transmitted light. It is therefore wellsuited for cabochons. Only some paler varieties are almost opaque.

In transmitted light a more yellowish green colouration can be observed compared to the more bluish green tint in reflected incandescent light. This phenomenon seems to be connected with the turbidity causing weak opalescence such as is common in chalcedony and opal. In the latter cases, it can be explained by the Tyndall effect (see Nassau 1983). In reflected light the shorter wavelenghts (blue light) are preferentially scattered from small irregularities (spherules, chalcedony fibres, etc.).

\section{Hardness}

Polished surfaces have a hardness of $6 \frac{1}{2}$ on the Moh's scale. Fracture surfaces are slightly below 7 on the Moh's scale. The lower hardness of the polished surfaces may be explained by the exposed opal and chalcedony component. Fracture surfaces exhibit protruding quartz crystals, which increase the hardness.

\section{Reaction to ultraviolet radiation}

Under long-wave and short-wave ultraviolet radiation the material is inert. The very low $\mathrm{U}$ contents $(0.3 \mathrm{ppm})$ present as an activator in the Tanzanian chrysoprase explain the absence of greenish fluorescence, typical of chalcedony and opal under UV-light excitation (see Zielinski 1982, Robbins 1983, Waychynas 1988). In one specimen the spherules and the edges of the chrysoprase vein show whitish fluorescence under short-wave radiation. This was, however, not observed with cut stones.

\section{Colour filter reaction}

The material stays green when viewed through the Chelsea colour filter. This shows that the colouring agent is similar to that of other chrysoprases (see Anderson 1980, Webster 1983).

\section{Polariscope reaction}

The material exhibits clear aggregate birefringence, which is common in chalcedonies.

\section{Spectroscopy}

The absorption spectra in transmitted and reflected light was observed with a Rayner prism spectroscope and OPL diffraction grating spectroscope. Both instruments failed to show distinct absorption bands or lines which have been reported for some chrysoprases (see Chuboda and Gübelin 1966, Liddicoat 1977). However, absorption in the red upward and violet blue downward 
increase as the sample thickness increases. This is in agreement with the observations published by Koivula and Fryer (1984) on chrysoprase in general and on green, nickeliferous opal from Tanzania.

\section{Reaction to heat}

Reaction to heat is a particularly important parameter for jewellers, because high temperatures used in mounting cut gems to jewellery findings can cause severe damage to some gem materials. In the case of chrysoprase, bleaching to greyish material with dark spots on the surface (nickel salts?) began at about $400^{\circ} \mathrm{C}$. The bleaching temperature was measured with Chaix Meca and Leitz 1350 microscope heating stages. In heating experiments no colour change to carnelian was noted although this is common in some chalcedonies (see Sinkankas 1988). This lack of colour change can be explained by the low iron content $(40 \mathrm{ppm})$ of the Tanzanian chrysoprase.

\section{Microscopy}

Gemmological microscopy is generally performed with high-quality stereomicroscopes equipped with specific illumination systems (bright-field, dark-field, overhead, etc.) using magnifications from 10x to 60x. Under this magnification the Tanzanian chrysoprase already reveals several diagnostic features although the material is only partly transparent. These features include spherules, cloudy colour distribution, clear chalcedony veinlets, whitish dots (microcavities), small fluid inclusions in bipyramidal quartz, and brownish inclusions of host rock.

In reflected light, relief can be observed in some cabochons (Fig. $3 \mathrm{~A}$ ). This is due to undercutting by the spherules. The main reason for this is the lower hardness of the opal component. In transmitted light the spherules are seen as small grayish dots. Using the shadowing illumination technique (described by Gübelin and Koivula, 1986), they are seen as multiring ovoids.
These spherules are the most characteristic feature of the Tanzanian chrysoprase, and consequently they are described in more detail.

\section{Spherules}

Microtextures were studied from ordinary thin sections using combinations of phase contrast, dark-field and ordinary transmitted polarized light (Fig. 3 B, C). The silica phases identified were: quartz, chalcedony, quartzine (chalcedony in length-slow form) and opal-A. These minerals are in agreement with the $\mathrm{X}$-ray diffraction analysis. Only a few mica flakes and carbonate rhombs were found as accessory minerals. Silicified fragments of the host rock, siliciophites, were common near the edges of the chrysoprase veins. These siliciophite fragments are petrographically similar to the birbiritized dunites described by Augustithis (1979, p. 96-97).

Spherules are characteristic of every section studied. Their abundance is variable, from almost pure spherule rocks to spherule-rich zones outlining former open spaces or vugs. The mean diameter of the spherules was $54 \mu \mathrm{m}$, with a standard deviation of $8 \mu \mathrm{m}$ and range from $40 \mu \mathrm{m}$ to $77 \mu \mathrm{m}$ (Fig. 4). The main types of the silica spherules and the arrangement of the concentric shells from the center to the rim were:

(1) bipyramidal quartz $\rightarrow$ chalcedony $\rightarrow$ opal-A,

(2) bipyramidal quartz $\rightarrow$ chalcedony,

(3) chalcedony $\rightarrow$ opal-A, and

(4) quartzine $\rightarrow$ opal-A.

The polymorphic transformation of opal-A to opal-CT and finally to chalcedonic quartz is a well-studied diagenetic process in silica precipitates (see Kastner 1979, Loretta et al. 1985, Williams and Crerar 1985, Williams et al. 1985). The presence of opal-A is evidence for a geologically recent age for the precipitate, usually younger than Tertiary (Stein 1982).

For comparison, the silica spherule size was measured from Tanzanian green opals. The or- 

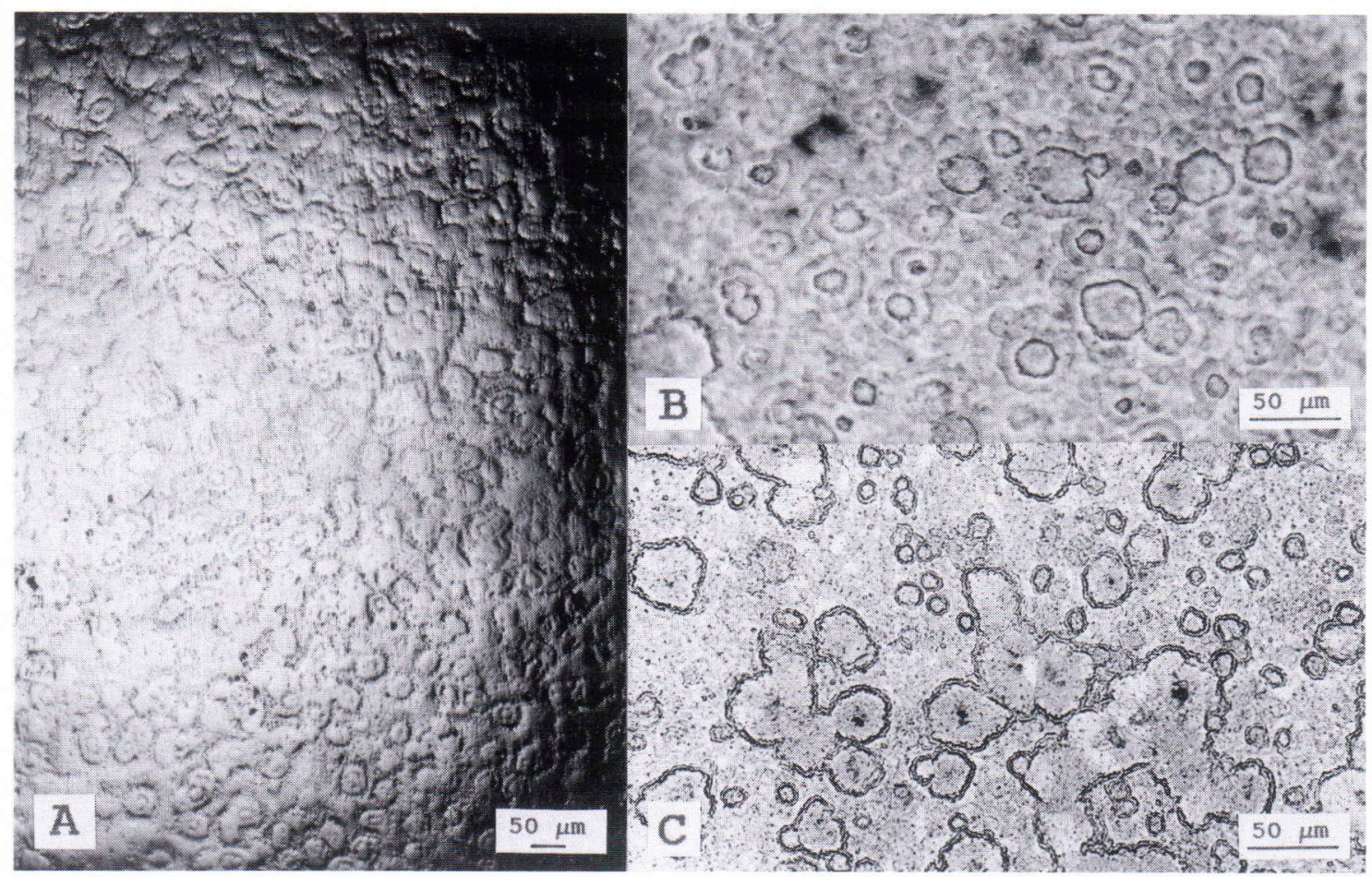

Fig. 3. Silica spherules are the most distinctive inclusion feature in gem-quality chrysoprase from the Haneti-Itiso area, Tanzania. Different microscope techniques are used to enhance the texture. A - Oblique reflected light photomicrograph from the polished lower surface of a cabochon showing the pronounced surface texture. The spherules are clearly seen because of undercutting resulting from the polishing of the cabochon. The opal component in the spherules is more deeply excavated because of its lower hardness. B - Phase contrast, transmitted light photomicrograph showing the spherule texture from thin section. The zonal structure of the spherules is clearly seen because the phase contrast technique enhances the phases having slightly different refractive indices. C - Transmitted, highly collimated, plane-polarized light photomicrograph enhancing the opal-A rim of the spherules from thin section. The opal rim is dark because of its low refractive index. Photomicrographs by K. A. Kinnunen.

dering of the spherules was weak and diameters ranged from $5.4 \mu \mathrm{m}$ to $6.8 \mu \mathrm{m}$, which is about an order of magnitude smaller than in the Tanzanian chrysoprase. However, their size is still about ten times too large to be able to cause any play of color in these opals.

\section{Ordering}

The arrangement of the silica spherules was highly disordered. They were found to coat former open spaces and none of the regular ordering observed in precious opals was found (see Dar-

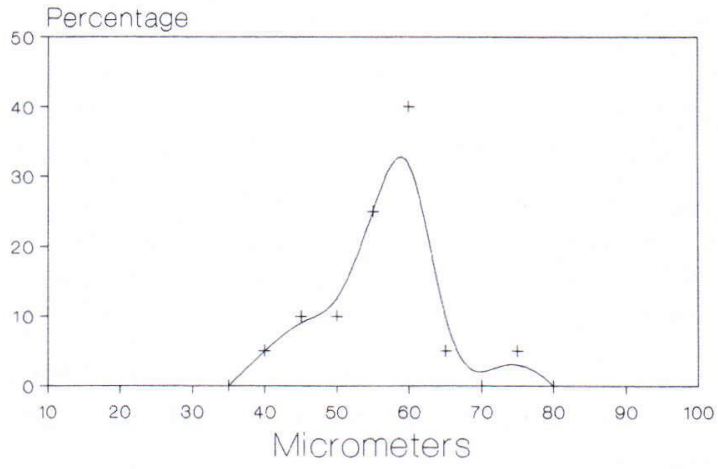

Fig. 4. Size distribution of silica spherules in gem-quality chrysoprase from Haneti-Itiso area, Tanzania. 
ragh et al. 1976). The unfilled voids still present in the chrysoprase samples were lined with slightly larger spherules and typical colloform textures. The mean diameter of these spherules was $74 \mu \mathrm{m}$, with a standard deviation of $12 \mu \mathrm{m}$ and a range from $54 \mu \mathrm{m}$ to $92 \mu \mathrm{m}$.

\section{Fluid inclusions}

Gemmologically useful fluid inclusion observations should be obtainable using nondestructive methods without heating and freezing experiments, so that data can be obtained for cut stones as well (see the Chapter by E. Roedder in Gübelin and Koivula 1986).

In chrysoprase some bipyramidal quartz crystals in the center of spherules contain small fluid inclusions. At room temperature they are monophasic with liquid filling. According to the crushing stage tests they are water inclusions, because they are devoid of gas under pressure. In the fluid inclusion classification used by Kinnunen (1989), they belong to the primary, pseudosecondary and secondary monophase liquid types (P5, PS5 and S5). Liquid inclusions with no vapour phase at room temperature have been shown to have formed at very low temperatures (Arnold 1986). Accordingly, the presence of P5 and PS5 inclusions, which lack the vapour phase, strongly indicate a very low crystallizing temperature. The S5 inclusions may have formed during later fracturing not directly connected with chrysoprase crystallization.

Similar fluid inclusion types have been described for chrysoprase occurring in serpentinites from Lower Silesia, Poland (Kozlowski and Sachanbinski 1984). The homogenization temperature of "cold-water» fluid inclusions have been determined for quartz from chrysoprase of the deposits in Central Kazakhstan as $40^{\circ} \mathrm{C}$ to $45^{\circ} \mathrm{C}$ (Samsonov and Menchinskiy 1977). Laboratory synthesis experiments have confirmed that quartz - not only opal and chalcedony - can crystallize even at room temperature, $20^{\circ} \mathrm{C}$ (Mackenzie and Gees 1971).

\section{Crystallization environment}

The origin of chrysoprase veins can be interpreted as (1) direct products of silica polymorph crystallization in open spaces, or as (2) replacements from some precursor material, e.q., carbonate veins. The replacement origin is excluded by the absence of any replacement textures and the scarcity of accessory minerals which could be interpreted as replacement relicts. The inner textures of the silica spherules testify to rhythmic primary crystallization of the silica phases quartz, chalcedony and opal. However, some of the quartzine spherules may represent crystallization products from opal precursors by ageing processes (cf. Kastner 1979). It should be noted that green opals occur in the same areas as the chrysoprase veins in the Haneti-Itiso area.

The rhythmic crystallization from quartz, via chalcedony to opal suggests increasing supersaturation of water with silica during each cycle (cf. Roedder 1968). Similar rhythmic patterns characterize, for example, some agate geodes (Augustithis 1982, Frondel 1985). It seems that a specific regular rhythmic process, leading to high supersaturation in the depositional fluid in each cycle, was responsible for the chrysoprase deposition.

Basset (1954) has studied the silica formations in Tanzania and ascribed them to surface waters. His interpretation agrees with the presence of P5 and PS5 fluid inclusions in chrysoprase. If Basset's interpretation is correct, the observed microtextures in chrysoprase suggest rhythmic supersaturation cycles due to repeated evaporation of supergene waters - or other low temperature fluids - which later infiltrated into open fractures and voids in the serpentinite.

Possible mechanisms for these supersaturation cycles are silcret weathering processes (Summerfield 1983a, Thiry and Millot 1987) and water circulation in hot lake environments. Silcretic processes could explain silica precipitation as ground water moves upwards by capillary action, evaporates and supersaturates in hot and arid 
tropical conditions. According to Summerfield (1983b), the M-fabric type microtexture (observed atso in the Tanzanian chrysoprase), with its colloform features and authigenic spherules, is especially common in weathering profile silcretes in Africa but absent from nonweathering profile types.

\section{Analogy with precious opals}

A similar explanation - the progressive evaporation of surface waters - has been offered for the origin of precious opal veins, associated with gypsum in sandstones at Andamooka, Cooper Pedy, and Lightning Ridge in Australia (Darragh et al. 1966, 1976). In the Australian precious opal the play of colour is ascribed to the diffraction of light from ordered spherical silica bodies, $0.1-0.3 \mu \mathrm{m}$ in diameter (ibid.). These silica bodies act as a three-dimensional optical diffraction grating (ibid.). The silica spherules in precious opal are likewise concentric (usually $2-3$ shells) but composed exclusively of opal-A. The electron diffraction patterns and transmission electron

\section{References}

Anderson, B.W., 1980. Gem Testing. Ninth edition. Butterworths, London, $434 \mathrm{p}$.

Arnold, M., 1986. So-called metastable monophase aqueous fluid inclusions at room temperature. C. R. Acad. Sci. Paris 303, Ser. II, No. 6, 459-461. (In French. Translation in Roedder, E. and Kozlowski, A. eds., Fluid Inclusion Research, Proceedings of COFFI 19, 499-501, University of Michigan Press.)

Augustithis, S.S., 1979. Atlas of the Textural Patterns of Basic and Ultrabasic Rocks and their Genetic Significance. Walter de Gruyter, Berlin, 396 p.

Augustithis, S.S., 1982. Atlas of the Sphaeroidal Textures and Structures and their Genetic Significance. Theophrastus, Athens, $329 \mathrm{p}$.

Basset, H., 1954. Silicification of rocks by surface waters. Amer. J. Sci. 252, 733-735.

Bauer, M., 1904. Precious Stones. Reprinted in 1968 from the English translation. Dover, New York, 627 p.

Chuboda, K.F. and Gübelin, E.J., 1966. Edelsteinkundliches photographs (Sanders 1975) have revealed that spherules in common, potch opals are likewise concentric (up to 5 shells) although of varying shape and size. Furthermore, the spherules in potch opals are composed of a mixture of amorphous and crystalline silica (ibid.), as observed in Tanzanian chrysoprase.

Acknowledgments. We are grateful to Professor, Dr. Eduard Gübelin, Lucerne, Switzerland, and Mr. John I. Koivula, Gemological Institute of America, Santa Monica, California, for critical reviews of the original manuscript and many valuable and helpful suggestions. In addition, the author (K.A.K.) expresses his genuine gratitude to Dr. Gübelin for instructive exchange of ideas over many years concerning the use of inclusions in gem testing. Both of us are grateful to Dr. Martti Lehtinen of the Department of Geology, University of Helsinki, for the X-ray analysis and guiding one of us (E.J.M.) in X-ray analytical interpretations. Drs. Tapio Koljonen and Antti Vuorinen from the Geological Survey of Finland, Espoo, and Department of Geology, University of Helsinki, respectively, are thanked for the chemical analyses. Mr. Boris Saltikoff, Geological Survey of Finland, Espoo, is especially thanked for critically reading the manuscript, using his wide experience on the economic geology in East Africa. Dr. Peter Ward, Geological Survey of Finland, Espoo, is thanked for English correction of the final manuscript.

Handbuch. Second edition. Wilhelm Stollfuss Verlag, Bonn, 277 p.

Connolly, R.R., 1980. Mineral Resources of Western Australia. Department of Mines, Perth, Western Australia, $90 \mathrm{p}$.

Darragh, P.J., Gaskin, A.J., Terrel, B.C., and Sanders, J.V., 1966. Origin of precious opal. Nature 209, 13-16.

Darragh, P.J., Gaskin, A.J., and Sanders, J.V., 1976. Opals. Sci. Amer. 234 (4), 84-95.

Fleet, A.J., 1984. Aqueous and sedimentary geochemistry of the rare earth elements. Pp. 343-373 in Rare Earth Element Geochemistry, ed. P. Henderson, Developments in Geochemistry 2. Elsevier, Amsterdam.

Frondel, C., 1962. Silica minerals. The System of Mineralogy, Vol. III. Wiley, New York, 334 p.

Frondel, C., 1985. Systematic compositional zoning in the quartz fibers of agates. Amer. Miner. 70, 975-979.

Frey, F.A., 1984. Rare earth element abundances in upper mantle rocks. Pp. 153-203 in Rare Earth Element Geochemistry, ed. P. Henderson, Developments in Geochemistry 2. Elsevier, Amsterdam. 
Gübelin, E., 1975. The Color Treasure of Gemstones. Elsevier Phaidon, London, 137 pp. Illustrated in color.

Gübelin, E.J. and Koivula, J.I., 1986. Photoatlas of Inclusions in Gemstones. ABC Edition, Zürich, 532 p.

Hurlbut, C.S., Jr., 1984. The jeweler's refractometer as a mineralogical tool. American Mineralogist 69, 391-398.

Kastner, M., 1979. Silica polymorphs. Pp. 99-109 in Marine Minerals, ed. R.G. Burns. Short Course Notes, Vol. 6. Mineralogical Society of America, Washington, D.C.

Kinnunen, K.A., 1982. Primary sedimentary features in Kittilä jasper, Finnish Lapland. Bull. Geol. Soc. Finland 54, $1-2,69-76$.

Kinnunen, K.A., 1989. Determination of total contents of fluid inclusions in quartz using modal analysis: examples from Proterozoic rocks and ore deposits in Finland. Bull. Geol. Soc. Finland 61, Part 2, 197-208.

Koivula, J.I. and Fryer, C.W., 1984. Green opal from East Africa. Gems \& Gemology 20, 226-227.

Komov, I.L., Lukashev, A.N. and Koplus, A.V., 1987. Geochemical Methods of Prospecting for Nonmetallic Minerals. VNU Science Press, Utrecht, 241 p.

Kozlowski, A. and Sachanbinski, M., 1984. Remarks on genesis of Polish chrysoprase as indicated by inclusion studies. Spraw. Pos. Kom. Nauk PAN 28, no. 1. (In Polish. Translation in COFFI 17, 402-404, 1984.)

Kunz, G.F., 1892. Gems and Precious Stones of North America. Reprint in 1968 of the second edition. Dover, New York, $367 \mathrm{p}$.

Lewis, D., 1977. Practical Gem Testing. N.A.G. Press Limited, London, $149 \mathrm{p}$.

Liddicoat, R.T., Jr., 1977. Handbook of Gem Identification. Tenth edition. Second printing. Gemological Institute of America, Santa Monica, $440 \mathrm{p}$.

Loretta, A.W., Parks, G.A., and Cerar, D.A., 1985. Silica diagenesis, I. Solubility controls. J. Sed. Petrol. 55, $301-311$.

Mackenzie, F.T. and Gees, R., 1971. Quartz: Synthesis at earth-surface conditions. Science, 533-535.

Malisa, E., 1987. Geology of the tanzanite gemstone deposits in the Lelatema area, NE Tanzania. Annales Academiae Scientiarum Fennicae III, Geologica-Geographica, 146, $160 \mathrm{p}$.

Malisa, E. and Muhongo, S., 1990. Tectonic setting of gemstone mineralization in the Proterozoic metamorphic terrane of the Mozambique Belt in Tanzania. Precambrian Res. 46, 167-176.

Matlins, A.L. and Bonanno, A.C., 1989. Gem Identification Made Easy. Gemstone Press, South Woodstock, 270 p.

Nassau, K., 1983. The Physics and Chemistry of Color. Wiley, New York, 454 p.

Osipov, P.V. and Klimovitskaya, E.F., 1977. Conditions for the formation of the chrysoprase in the Sarakulboldy deposit of central Kazakhstan. Pp. 153-164 in Namet. Polezn. Iskop. Kory Vyvetrivaniya, eds. Petrov, V.P. and Smolin, P.P., Izd. Nauka, Moscow. (In Russian, abstract translated in COFFI 11, 156-157.)

Pallister, J.W., 1960. Brief explanation of the geology of Q.D.S. 124, Kelema, Geological Map, 1:125 000. Geol. Surv. Div., Dodoma, Tanzania.

Pallister, J.W., 1963. Brief explanation of the Geology of Q.D.S. 143, Meia Meia. Geol. Surv. Div., Dodoma, Tanzania.

Robbins, M., 1983. The Collector's Book of Fluorescent Minerals. Van i lostrand Reinhold, New York, 289 p.

Roedder, E., 1968. The noncolloidal origin of »colloform» textures in sphalerite ores. Econ. Geol. 63, 451-471.

Samsonov, Y.P. and Menchinskiy, V.V., 1977. Geologicalstructural pecularities and formation conditions of the chrysoprase deposit Sarakulboldy (Central Kazakhstan). Pp. 147-152 in Non-metallic mineral raw materials of weathering crust, Nauka, Moscow. (In Russian, abstract translated in COFFI 13, 219, 1980.)

Sanders, J.V., 1975. Microstructure and crystallinity of gem opals. Amer. Miner. 60, 749-757.

Schmetzer, K., Berdesinski, W. and Krupp, H., 1976. Grüner Opal aus Tanzania. Aufschluß 27, 381-384.

Sinkankas, J., 1988. Gemstone \& Mineral Data Book. Geoscience Press, Prescott, 352 p.

Stein, C.L., 1982. Silica recrystallization in petrified wood. J. Sed. Petrol. 52, 1277-1282.

Summerfield, M.A., 1983a. Silcrete. Pp. 59-91 in Chemical Sediments and Geomorphology: Precipitates and Residua in the Near-surface Environment, eds. A.S. Goudie and K. Pye, Academic Press, London.

Summerfield, M.A., 1983b. Petrography and diagenesis of silcrete from the Kalahari Basin and Cape Coastal zone, southern Africa. J. Sedim. Petrol. 53, 895-909.

Thiry, M. and Millot, G., 1987. Mineralogical forms of silica and their sequence of formation in silcretes. J. Sedim. Petrol. 57, 343-352.

Waychunas, G.A., 1988. Luminescence, X-ray emission and new spectroscopies. Pp. 639-698 in Spectroscopic Methods in Mineralogy and Geology, ed. F.C. Hawthorne, Reviews in Mineralogy, Vol. 18, Mineralogical Society of America, Washington, D.C.

Webster, R., 1983. Gems. Their Sources, Descriptions and Identification. Fourth edition, revised by B.W. Anderson. Butterworths, London, $1006 \mathrm{p}$.

Williams, L.A. and Crerar, D.A., 1985. Silica diagenesis, II. General mechanisms. J. Sedim. Petrol. 55, 312-321.

Williams, L.A., Parks, G.A., and D.A. Crerar, 1985. Silica diagenesis, I. Solubility controls. J. Sedim. Petrol. 55, $301-311$.

Zielinski, R.A., 1982. Uraniferous opal, Virgin Valley, Nevada: Conditions of formation and implications for uranium exploration. J. Geochem. Explor. 16, 197-216.

Received June 8, 1990

Revision accepted September 13, 1990 